\title{
DNA Variation in the Genes of the Na,K-Adenosine Triphosphatase and Its Relation with Resting Metabolic Rate, Respiratory Quotient, and Body Fat
}

Olivier Dériaz, France Dionne, Louis Pérusse, Angelo Tremblay, Marie-Claude Vohl, Guylaine Côté, and Claude Bouchard Physical Activity Sciences Laboratory, Laval University, Ste-Foy, Québec G1K 7P4, Canada

\begin{abstract}
The aim of this study was to investigate in 261 subjects from 58 families the association between DNA variation at the genes coding for the Na,K-ATPase peptides and resting metabolic rate (RMR), respiratory quotient ( $R Q)$, and percent body fat (\%FAT). Five restriction fragment length polymorphisms (RFLP) at three Na,K-ATPase genes were determined: one at the $\alpha 1$ locus (BglII), two at the $\alpha 2$ locus ( $\alpha 2$ exon 1 and $\alpha 2$ exon 21-22 with BgIII), and two at the $\beta$ locus ( $\beta$ MspI and $\beta$ PvuII). Haplotypes were determined from the two variable sites of the $\alpha 2$ gene ( $\alpha 2$ haplotypes) and the $\beta$ gene ( $\beta$ haplotypes). There was a strong trend for \%FAT to be related to the RFLP generated by BglII at the $\alpha 2$ exons 21-22 in males ( $P$ $=0.06)$ and females $(P=0.05)$. RQ was $(a)$ associated with the Bgl II RFLP at the $\alpha 2$ exon $1(P=0.02)$ and with the $\alpha 28.0$ $\mathrm{kb} / 4.3 \mathrm{~kb}$ haplotype $(P=0.04)$ and $(b)$ linked with the $\beta$ gene MspI marker $(P=0.04)$ and with the $\beta 5.3 \mathrm{~kb} / 5.1 \mathrm{~kb}$ haplotype $(P=0.008)$ based on sib-pair analysis. The present study suggests that the genes encoding $\mathrm{Na}, \mathrm{K}$-ATPase may be associated or linked with RQ and perhaps with \%FAT but not with RMR. (J. Clin. Invest. 1994. 93:838-843.) Key words: body composition • $\mathrm{Na}, \mathrm{K}$-ATPase genes • polymorphism • respiratory quotient $\bullet$ resting energy expenditure
\end{abstract}

\section{Introduction}

Low resting metabolic rate ( $\mathrm{RMR}),{ }^{1}$ adjusted for age, gender, and body composition was reported to be a risk factor for longterm body weight gain (1). Moreover, familial and twin study data suggest that the RMR variability has a genetic component (2-4). Thus, even though the evidence supporting this notion is still rather weak, the previous studies suggest that an individual with a low RMR may be genetically more at risk of weight gain. RMR variability depends on several biochemical pathways that are known to consume energy, i.e., $\mathrm{Na}, \mathrm{K}$-ATPase activity, protein synthesis, substrate cycling, and others.

Address correspondence to Dr. Claude Bouchard, Physical Activity Sciences Laboratory, PEPS, Laval University, Ste-Foy, Québec, Canada G1K 7P4.

Received for publication 6 July 1993 and in revised form 20 September 1993.

1. Abbreviations used in this paper: BMI, body mass index; FM, fat mass; FFM, fat-free mass; \%FAT, percent body fat; RQ, resting quotient; RMR, resting metabolic rate.

J. Clin. Invest.

(C) The American Society for Clinical Investigation, Inc.

$0021-9738 / 94 / 02 / 0838 / 06 \$ 2.00$

Volume 93, February 1994, 838-843
The Na,K-ATPase is ubiquitous in the organism and its basic function is to ensure the energy-dependent cation transport across the cell membrane. The relative contribution of this enzyme to RMR remains controversial. Animal data suggest that $\mathrm{Na}, \mathrm{K}-\mathrm{ATPase}$ oxygen consumption represents $\sim 20-40 \%$ of the whole-body oxygen consumption $(5,6)$. However, the importance of the $\mathrm{Na}, \mathrm{K}-\mathrm{ATPase}$ energy expenditure varies with the body constituent considered. For instance, the proportion of energy expenditure accounted for by the Na,K-ATPase activity may be $4-10 \%$ for the skeletal muscle, $<5 \%$ for the liver, $>50 \%$ for the kidneys, and $40-50 \%$ for the brain (6).

The activity of $\mathrm{Na}, \mathrm{K}-\mathrm{ATPase}$ influences the intra- and extracellular cation concentration and consequently the membrane potential. It has been shown that membrane depolarization reduces hepatic oleate uptake (7). Moreover, after a treatment with ouabain, which is known to inhibit the $\mathrm{Na}, \mathrm{K}-\mathrm{ATPase}$, oleate uptake by isolated rat heart myocytes was reduced by $38 \%(8)$. Thus, the $\mathrm{Na}, \mathrm{K}-\mathrm{ATPase}$ may influence the intracellular free fatty acid concentration and, as described by Randle et al. (9), it may impact on the relative nutrient oxidation rate, i.e., the respiratory quotient (RQ).

The Na,K-ATPase is constituted of a catalytic subunit $(\alpha)$ and a second subunit $(\beta)$, which has an unknown function. The $\alpha$ subunit has three isoforms $(\alpha 1, \alpha 2$, and $\alpha 3)$ coded by separate genes (10). The $\alpha 1$ gene expression is ubiquitous (with a high concentration in the kidneys), the $\alpha 2$ is expressed mainly in the skeletal muscle, and the $\alpha 3$ in the brain. DNA RFLPs have been described for each of these genes (11-13). The RFLPs are used here as DNA markers.

The aim of the present study is to investigate the relationship of RMR, RQ, and percent body fat (\%FAT) with DNA sequence variations in the genes coding the $\alpha 1, \alpha 2$, and $\beta$ subunits of the $\mathrm{Na}, \mathrm{K}-\mathrm{ATPase}$.

\section{Methods}

Subjects. A total of 261 individuals from 58 families of the Québec Family Study were available for the present study. Subjects were of French descent living within $80 \mathrm{~km}$ around Québec City. These subjects were recruited through the media between 1978 and 1981. Since 1989 , a second set of tests has been performed on these subjects and data from the latter period are used in the present study. The population was in general rather healthy with $>80 \%$ being free of symptoms or clinical conditions. The others were hypertensive, diabetic, or coronary heart disease patients or had minor orthopedic problems. The percentages of nonobese (body mass index [BMI] $<27 \mathrm{~kg} / \mathrm{m}^{2}$ ), alcohol abstinents, and nonsmokers were $83 \%, 45 \%$, and $85 \%$, respectively. The characteristics of the subjects are presented in Table I.

Phenotype determination. Indirect calorimetry measurements were performed in the morning. The subjects were in a fasted state for $12 \mathrm{~h}$ and sat quietly in a semireclined position during the measurement for at least $30 \mathrm{~min}$. The last $10 \mathrm{~min}$ of measurement were kept for calculations. Energy expenditure and substrate oxidation rates were calculated from the respiratory exchange data, which were measured continuously using a ventilated hood with an open-circuit indirect calorimeter 
Table I. Characteristics of the Subjects

\begin{tabular}{lccccc}
\hline & \multicolumn{2}{c}{ Parents } & & \multicolumn{2}{c}{ Offspring } \\
\cline { 2 - 3 } \cline { 5 - 6 } \multicolumn{1}{c}{ Variable } & Men & Women & & Men & Women \\
\hline Sample size* & 67 & 56 & & 79 & 69 \\
Age $(y r)$ & $55 \pm 6$ & $52 \pm 5$ & & $25 \pm 5$ & $25 \pm 4$ \\
Body mass $(\mathrm{kg})$ & $77 \pm 12$ & $63 \pm 9$ & & $72 \pm 10$ & $58 \pm 7$ \\
Height $(\mathrm{cm})$ & $171 \pm 6$ & $159 \pm 5$ & & $176 \pm 6$ & $163 \pm 6$ \\
BMI $\left(\mathrm{kg} / \mathrm{cm}^{2}\right)$ & $26 \pm 4$ & $25 \pm 4$ & & $23 \pm 3$ & $22 \pm 3$ \\
Percent fat & $26 \pm 6$ & $37 \pm 8$ & & $17 \pm 7$ & $25 \pm 7$ \\
RMR $(\mathrm{kJ} / \mathrm{min})$ & $4.7 \pm 0.6$ & $3.7 \pm 0.5$ & & $4.9 \pm 0.5$ & $4.0 \pm 0.4$ \\
RQ & $0.83 \pm 0.04$ & $0.81 \pm 0.04$ & & $0.81 \pm 0.04$ & $0.82 \pm 0.05$ \\
& & & & &
\end{tabular}

Means \pm SD.

* The maximal number of subjects is given. The number may vary for various loci and restriction sites (see Table II).

(14). Gas analyses were made with an infrared carbon dioxide analyzer (Amatek S-3A, Thermox Instruments Division, Pittsburgh, PA) and a zirconia cell oxygen analyzer (Amatek CD-3A). These analyzers were calibrated just before the indirect calorimetry measurements. Body density was determined by underwater weighing using standard procedures and residual volume was assessed by the helium dilution technique (15). The Siri equation (16) was used to estimate percent body fat from body density. Resting metabolic rate and body density have been shown to be reproducible with coefficients of variation of $5.6 \%$ and $0.4 \%$, respectively (17).

DNA probes. All probes were generously given by Dr. J. B. Lingrel (University of Cincinnati). They have been shown to identify polymorphisms with codominant mendelian inheritance (11-13). The following genomic probes were used in the present study: $(a) \alpha 1$ probe is a 1.0 $\mathrm{kb}$ DNA fragment of the first intron of the $\alpha 1$ gene (ATP1Al gene); (b) $\alpha 2$ exon 1 probe is a 2.5-kb DNA fragment of the $5^{\prime}$ end of the $\alpha 2$ gene (ATP1A2 gene) that includes exon $1 ;(c) \alpha 2$ exon $21-22$ probe is a 1.0-kb DNA fragment of the $3^{\prime}$ portion of the $\alpha 2$ gene (ATP1A2 gene) that includes exons 21 and $22 ;(d) \beta$ probe is a $1.2-\mathrm{kb}$ DNA fragment from the 3 ' portion of the $\beta$ gene (ATP1B1 gene).

Genotype determination. Genomic DNA was isolated from lymphoblastoid cell cultures by digestion with proteinase $\mathrm{k}$ and extraction with phenol chloroform. DNA samples $(5 \mu \mathrm{g})$ were digested with restriction enzymes ( $a$ ) Bgl II for the $\alpha 1$ and $\alpha 2$ genes and $(b)$ MspI and PvulI for $\beta$ gene. The resulting DNA fragments were separated on a $1.2 \%$ agarose gel electrophoresis and transferred to nylon filters (18). Genomic probes were labeled with phosphorus 32 using the random priming technique (19). The filters were prehybridized for $4 \mathrm{~h}$ in a hybridization incubator model 310 (Robbins Scientific Corp., Sunnyvale, CA) with a solution containing $250 \mathrm{mM} \mathrm{Na}_{2} \mathrm{HPO}_{4}, 1 \mathrm{mM}$ EDTA, SDS 7\%, and $0.1 \mathrm{mg} / \mathrm{ml}$ salmon sperm DNA. The filters were then hybridized with the ${ }^{32} \mathrm{P}$-labeled probes $(0.5 \mu \mathrm{Ci} / \mathrm{ng}$ of probe $)$ for $12 \mathrm{~h}$ in the same buffer. Filters were washed three times for $20 \mathrm{~min}$ with a solution containing $19.5 \mathrm{mM} \mathrm{NaCl}, 1 \mathrm{mM} \mathrm{NaH} \mathrm{PO}_{4}, 0.1 \mathrm{mM}$ EDTA, and SDS $0.1 \%$ (pH 7.7). Autoradiograms were developed after $1-7 \mathrm{~d}$ of exposure at $-70^{\circ} \mathrm{C}$ with Kodak X-OMAT AR films and intensifying screens. The sizes of the DNA fragments were estimated using phage lambda DNA digested with HindIII and EcoRI as size standards.

Statistical analyses. A chi square test was performed to assess whether the observed genotype frequencies followed the Hardy-Weinberg distribution. Linkage disequilibrium between two loci was tested with the method described by Thompson et al. (20). Briefly, if $p$ and $q$ are the rare allele frequencies at two loci, $N$ the number of subjects, and $h$ the frequency of the haplotype with the rare allele at both loci, the linkage disequilibrium $D=h-p q$. If $p$ is smaller than $q$, the maximum possible value of $D\left(D_{\max }\right)=p \cdot(1-q)$ and the minimum possible is $-p q . D \%$ is the percentage of $D_{\min }$ or $D_{\max }$ achieved by $D$. The square of the standardized value of $D$ is: $D_{\mathrm{st}}{ }^{2}=D^{2} \cdot N /[p \cdot(1-p) \cdot q \cdot(1$ $-q)] . D_{\mathrm{st}}{ }^{2}$ follows a $\chi^{2}$ distribution with one degree of freedom (20). Thus, a $\chi^{2}$ test was performed to assess if $D_{\mathrm{st}}{ }^{2}$ is significantly different from zero.

For each gender and generation separately, RMR and RQ data were adjusted for fat free mass (FFM), fat mass (FM), and age and the residuals were used for analyses. The percentage of body fat (\%FAT) was adjusted only for age within gender and generation. As there was no difference between the genders, a two-factor ANOVA was used to detect differences in RMR and RQ between genotypes in unrelated adults (parents): one factor was gender and the other the genotype. Percentage of body fat was analyzed with a one factor (genotype) analysis of variance separately for each gender.

To investigate possible linkages between quantitative phenotypes and markers of $\mathrm{Na}, \mathrm{K}-\mathrm{ATPase}$ loci, the sib-pair linkage procedure was used (21). The principle of this method is that if a major gene is linked to or is the marker locus, the greater the proportion of marker alleles shared by two sibs, the smaller the squared difference between their phenotypic values will be. To test for the presence of linkage, the squared sib-pair phenotypic difference is regressed on the expected proportion of marker alleles identical by descent at each locus. A significant negative relationship between the squared sib-pair phenotypic difference and the marker locus is taken as evidence of linkage between the marker locus and the phenotype. The major advantage of this linkage method is that it does not require knowledge of the genetic model underlying the expression of the phenotype to be analyzed. This linkage analysis was performed using the program SIBPAL from SAGE $v$ $2.1(22)$.

DNA variant sites located in the same gene served to construct haplotypes, i.e., $\alpha 2$ gene haplotypes (constructed with $\alpha 2$ exon 1 and $\alpha 2$ exons 21-22 markers) and $\beta$ gene haplotypes (constructed with $\beta$ $\mathrm{MspI}$ and $\beta$ PvulI markers). For instance, an individual heterozygous $(8.0 \mathrm{~kb} / 3.3 \mathrm{~kb})$ at the $\alpha 2$ exon 1 locus and homozygous $(4.3 \mathrm{~kb} / 4.3$ $\mathrm{kb}$ ) at the $\alpha 2$ exon 21-22 locus carries the $\alpha 28.0-\mathrm{kb} / 4.3-\mathrm{kb}$ and the $\alpha 2$ 3.3-kb/4.3-kb haplotypes. Thus, in most circumstances, the genotypes are sufficient to determine the haplotypes. However, the haplotypes cannot be determined on a doubly heterozygous individual when the phase is not known, for instance someone with $\alpha 28.0-\mathrm{kb} / 3.3-\mathrm{kb}$ and $\alpha 2$ 10.5-kb/4.3-kb genotypes at $\alpha 2$ exon 1 and $\alpha 2$ exons 21-22 loci, respectively. This individual may carry either $(a) \alpha 28.0-\mathrm{kb} / 10.5-\mathrm{kb}$ and $\alpha 23.3-\mathrm{kb} / 4.3-\mathrm{kb}$ haplotypes or $(b) \alpha 28.0-\mathrm{kb} / 4.3-\mathrm{kb}$ and $\alpha 23.3-$ $\mathrm{kb} / 10.5-\mathrm{kb}$ haplotypes. It is generally possible to determine the parents' haplotypes from information on the children and the spouse. However, in some cases, the genotypes of the family members do not allow to determine the haplotypes.

The effect of each haplotype was assessed by separating subjects into three groups. For instance, in the analysis of the $\alpha 28.0-\mathrm{kb} / 10.5-\mathrm{kb}$ haplotype, groups of subjects were defined as follows: $(a)$ the first group was constituted of subjects who do not carry the $\alpha 28.0-\mathrm{kb} / 10.5-\mathrm{kb}$ haplotype, $(b)$ the subjects of the second groups carry only one copy of the $\alpha 28.0-\mathrm{kb} / 10.5-\mathrm{kb}$ haplotype, and $(c)$ the last group was constituted of subjects who carry two copies of the $\alpha 28.0-\mathrm{kb} / 10.5-\mathrm{kb}$ haplotype. In other words, the presence and the absence of a given haplotype was considered as a two-allele system. ANOVAs and sib-pair linkage analyses of the haplotypes were then performed as described for the biallelic markers.

It is often proposed to make an adjustment for multiple comparisons in studies of this kind. However, the adjustment for multiple comparisons increases the type II error (false negative results) and is, therefore, not always deemed necessary (23). In the present study, the number of these comparisons is not very high and an adjustment for multiple comparisons was not performed to minimize the risk of missing useful associations or linkages.

\section{Results}

Allele frequencies were close to those reported in the literature (Table II). The allele frequencies were 0.97 and 0.03 at the $\alpha 1$ 
Table II. Na,K-ATPase RFLP of the $\alpha$ and $\beta$ Subunits

\begin{tabular}{|c|c|c|c|c|c|}
\hline \multirow[b]{2}{*}{ Locus } & \multirow{2}{*}{$\begin{array}{l}\text { Restriction } \\
\text { enzyme }\end{array}$} & \multirow{2}{*}{$\begin{array}{l}\text { Allele } \\
\text { size }\end{array}$} & \multicolumn{2}{|c|}{ Allele frequencies* } & \multirow{2}{*}{$\begin{array}{c}\text { Allele } \\
\text { frequency }^{\ddagger}\end{array}$} \\
\hline & & & Absolute & Relative & \\
\hline & & $k b$ & & & \\
\hline \multirow[t]{2}{*}{$\alpha 1$} & BglII & 14.0 & 208 & 0.97 & 0.95 \\
\hline & & 11.5 & 6 & 0.03 & 0.05 \\
\hline \multirow[t]{2}{*}{$\alpha 2$ exon 1} & BglII & 8.0 & 179 & 0.88 & 0.85 \\
\hline & & 3.3 & 25 & 0.12 & 0.15 \\
\hline \multirow[t]{2}{*}{$\alpha 2$ exon $21-22$} & BglII & 10.5 & 39 & 0.18 & 0.20 \\
\hline & & 4.3 & 173 & 0.82 & 0.80 \\
\hline \multirow[t]{2}{*}{$\beta$} & MspI & 6.7 & 86 & 0.42 & 0.50 \\
\hline & & 5.3 & 118 & 0.58 & 0.50 \\
\hline \multirow[t]{2}{*}{$\beta$} & Pvull & 5.1 & 106 & 0.58 & 0.63 \\
\hline & & 4.7 & 78 & 0.42 & 0.37 \\
\hline
\end{tabular}

* Determined from the data of the unrelated adults of generation 1 (parents) only. ${ }^{\ddagger}$ The frequencies reported in the literature were computed from 10 unrelated subjects at the $\alpha 1$ and $\alpha 2$ sites $(8,9)$ and from 15 unrelated subjects at both $\beta$ sites (10).

locus, 0.88 and 0.12 at the $\alpha 2$ exon 1 locus, 0.82 and 0.18 at the $\alpha 2$ exon $21-22$ locus, 0.58 and 0.42 at the $\beta$ MspI locus and 0.58 and 0.42 at the $\beta$ PvulI locus, for the most frequent and rare allele, respectively. Genotype frequencies did not differ significantly from the values expected from the Hardy-Weinberg equilibrium. The values of genotype frequencies were (expected values in parentheses): $0.94(0.94), 0.06(0.06)$, and $0.00(0.00)$ for the $\alpha 1$ locus (not significantly different from Hardy-Weinberg equilibrium, $\left.\chi^{2}=0.08, \mathrm{df}=2\right) ; 0.76(0.77)$, $0.23(0.21), 0.01(0.01)$ for the $\alpha 2$ exon 1 locus $\left(\chi^{2}=0.24\right.$, NS, $\mathrm{df}=2) ; 0.67(0.67), 0.29(0.30)$, and $0.04(0.03)$ for the $\alpha 2$ exon $21-22$ locus $\left(\chi^{2}=0.07, \mathrm{NS}, \mathrm{df}=2\right) ; 0.37(0.34), 0.41$ (0.49), $0.22(0.18)$ for the $\beta$ MspI locus $\left(\chi^{2}=2.47, \mathrm{NS}, \mathrm{df}\right.$ $=2$ ); and finally $0.34(0.34), 0.48(0.49)$, and $0.18(0.18)$ for the $\beta$ Pvull locus $\left(\chi^{2}=0.04, \mathrm{NS}, \mathrm{df}=2\right)$ for the homozygous individuals with the frequent allele, for the heterozygous individuals and for the homozygous individuals with the rare allele, respectively.

There was no linkage disequilibrium between $\alpha 2$ exon 1 and $\alpha 2$ exon 21-22 loci. The value of $D$ and $D_{\min }$ reached -0.0183 and -0.0233 , respectively. Thus $D$ represented as much as $79 \%$ of its minimal value. Haplotype could be determined in all subjects and haplotype frequencies are shown in Table III. Because there is only one subject with the $\alpha 23.3-\mathrm{kb} /$ 10.5 -kb haplotype, all other subjects with allele $10.5 \mathrm{~kb}$ at exon 21-22 locus carry the $\alpha 28.0-\mathrm{kb} / 10.5-\mathrm{kb}$ haplotype (Table III). Thus, the frequencies of the $10.5-\mathrm{kb}$ allele and $\alpha 28.0-\mathrm{kb} /$ $10.5-\mathrm{kb}$ haplotype are about the same and therefore, the results for the $\alpha 2$ exon 21-22 genotypes and $\alpha 28.0-\mathrm{kb} / 10.5-\mathrm{kb}$ haplotype are similar. For that reason, data for this haplotype are not shown. Similarly, almost all subjects with the 3.3-kb allele at the $\alpha 2$ exon 1 locus have the $\alpha 23.3-\mathrm{kb} / 4.3-\mathrm{kb}$ haplotype and, therefore, only the results of the $\alpha 2$ exon 1 genotypes are shown.

Between $\beta$ MspI and $\beta$ Pvull sites, there was a significant linkage disequilibrium $(P<0.001)$. Both values of $D$ and $D_{\min }$ reached the value of -0.178 . Thus $D$ was equal to $100 \%$ of its minimal value. From the family genotypes, it was not possible
Table III. Distribution of Subjects among the Various Haplotypes

\begin{tabular}{lrr}
\hline \multicolumn{1}{c}{ Haplotype } & $N$ & $\begin{array}{c}\text { Haplotype } \\
\text { frequency }\end{array}$ \\
\hline Haplotypes at $\alpha 2$ exon 1 and $\alpha 2$ exon $21-22$ sites & & \\
$\alpha 28.0 \mathrm{~kb} / 10.5 \mathrm{~kb}$ & 37 & 0.183 \\
$\alpha 28.0 \mathrm{~kb} / 4.3 \mathrm{~kb}$ & 140 & 0.693 \\
$\alpha 23.3 \mathrm{~kb} / 10.5 \mathrm{~kb}$ & 1 & 0.005 \\
$\alpha 23.3 \mathrm{~kb} / 4.3 \mathrm{~kb}$ & 24 & 0.119 \\
Haplotypes at $\beta$ MspI and $\beta$ Pvull sites & & \\
$\beta 6.7 \mathrm{~kb} / 5.1 \mathrm{~kb}$ & 72 & 0.434 \\
$\beta 6.7 \mathrm{~kb} / 4.7 \mathrm{~kb}$ & 0 & 0.000 \\
$\beta 5.3 \mathrm{~kb} / 5.1 \mathrm{~kb}$ & 26 & 0.157 \\
$\beta 5.3 \mathrm{~kb} / 4.7 \mathrm{~kb}$ & 68 & 0.410 \\
& & \\
\hline
\end{tabular}

$N$, number of haplotypes.

to determine the haplotype of five parents and five children. Here, no subjects carried the $\beta 6.7-\mathrm{kb} / 4.7-\mathrm{kb}$ haplotype and, therefore, the presence of the $\beta 6.7-\mathrm{kb} / 5.1-\mathrm{kb}$ haplotype and the $5.3-\mathrm{kb} / 4.7-\mathrm{kb}$ haplotype corresponded exactly to the $6.7-$ $\mathrm{kb}$ allele at the $\beta \mathrm{MspI}$ locus and the $4.7-\mathrm{kb}$ allele at the $\beta$ PvuII locus, respectively.

The differences in RMR, RQ, and \%FAT between genotypes for the allele markers and the haplotypes are shown in Tables IV to VI. For RMR and RQ, no significant gender effect and no interaction between gender and genotype were observed in the two-factor ANOVA. When both genders were taken together, genotypes of the $\alpha 2$ exon 1 locus showed a difference in RQ $(P=0.02$, Table IV $)$. Moreover, the respiratory quotient was associated with the $\alpha 28.0-\mathrm{kb} / 4.3-\mathrm{kb}$ haplotype $(P<0.04$, Table VI $)$. Table $\mathrm{V}$ shows that percent body fat tends to be associated with the genotypes of the $\alpha 2$ exon 21-22 locus in men $(P=0.06)$ and women $(P=0.05)$. In both genders, the $10.5-\mathrm{kb}$ allele was associated with a low \%FAT. Moreover \%FAT of the women was also associated with the $\alpha 2$ $8.0-\mathrm{kb} / 4.3-\mathrm{kb}$ haplotype $(P=0.04)$. Table VII summarizes the results of all the ANOVAs performed in the present study.

Table VIII shows results of the sib-pair linkage analysis. With the $\beta$ gene MspI polymorphism, there is an inverse relationship between the proportion of genes identical by descent

Table IV. ANOVA for Differences in RMR, Percent Fat, and $R Q$ at the $\alpha 2$ Exon 1 Locus*

\begin{tabular}{lccccc}
\hline & \multicolumn{2}{c}{$\alpha 2$ exon 1 genotypes } & & \\
\cline { 2 - 3 } Phenotype & $8.0 \mathrm{~kb} / 8.0 \mathrm{~kb}$ & $8.0 \mathrm{~kb} / 3.3 \mathrm{~kb}$ & $F$ ratio & $P$ \\
\hline RMR & $4.20 \pm 0.04(78)$ & $4.17 \pm 0.06(24)$ & 0.14 & 0.70 \\
RQ & $0.816 \pm 0.005(78)$ & $0.840 \pm 0.009(24)$ & 5.72 & 0.02 \\
Percent fat & & & & \\
$\quad$ M & $25.5 \pm 1.1(37)$ & $27.0 \pm 1.7(14)$ & 0.54 & 0.46 \\
F & $36.3 \pm 1.1(41)$ & $36.0 \pm 2.2(10)$ & 0.02 & 0.89
\end{tabular}

Mean \pm SE. Abbreviations: $M$, males; $F$, females.

* From the unrelated adults only. RMR and RQ are adjusted for FFM, FM, and age. Percent fat is adjusted for age. Number of subjects in parentheses. $\$ 8.0-\mathrm{kb} / 3.3-\mathrm{kb}$ and $3.3-\mathrm{kb} / 3.3-\mathrm{kb}$ genotypes were combined together because there was only one subject with the 3.3$\mathrm{kb} / 3.3-\mathrm{kb}$ genotype. 
Table V. ANOVA for Differences in RMR, Percent Fat, and RQ at the $\alpha 2$ exon 21-22 Locus*

\begin{tabular}{|c|c|c|c|c|c|}
\hline \multirow[b]{2}{*}{ Phenotype } & \multicolumn{3}{|c|}{$\alpha 2$ exon 21-22 genotypes } & \multirow[b]{2}{*}{$F$ ratio } & \multirow[b]{2}{*}{$P$} \\
\hline & $10.5 \mathrm{~kb} / 10.5 \mathrm{~kb}$ & $10.5 \mathrm{~kb} / 4.3 \mathrm{~kb}$ & $4.3 \mathrm{~kb} / 4.3 \mathrm{~kb}$ & & \\
\hline RMR & $-(4)^{\ddagger}$ & $4.14 \pm 0.06(31)$ & $4.18 \pm 0.04(71)$ & 0.64 & 0.53 \\
\hline RQ & $-(4)^{\ddagger}$ & $0.815 \pm 0.008$ & $0.823 \pm 0.005(71)$ & 0.52 & 0.60 \\
\hline \multicolumn{6}{|l|}{ Percent fat } \\
\hline $\mathbf{M}$ & & $23.7 \pm 1.5(18)$ & $27.2 \pm 1.1(34)$ & 3.65 & 0.06 \\
\hline $\mathrm{F}$ & $29.7 \pm 3.3(4)$ & $34.6 \pm 1.9(13)$ & $37.7 \pm 1.1(37)$ & 3.23 & 0.05 \\
\hline
\end{tabular}

Mean \pm SE. Abbreviations: M, males; F, females.

* From the unrelated adults only. RMR and RQ are adjusted for FFM, FM, and age. Percent fat is adjusted for age. Number of subjects in parentheses. ${ }^{\ddagger}$ Results not shown because only one gender is represented in this genotype.

in a sib pair and the squared difference in $\mathrm{RQ}(P=0.04)$. Moreover RQ was linked with $\beta$ 5.3-kb/5.1-kb haplotype ( $P$ $=0.008)$. No other linkage was found between any of the gene markers and RMR, RQ, or \%FAT. There was an insufficient number of cases with the rare allele in the sample to perform the sib-pair linkage analysis with the $\alpha 1$ gene. For the same reason, no linkage and association analysis could be performed with the $\alpha 23.3-\mathrm{kb} / 10.5-\mathrm{kb}$ haplotype and the $\beta 6.7-\mathrm{kb} / 4.7-\mathrm{kb}$ haplotypes.

\section{Discussion}

Based on data obtained on 261 subjects from 58 nuclear families, we did not find any association between RMR and the various RFLPs of the genes encoding the $\alpha 1, \alpha 2$, and $\beta$ subunits of the Na,K-ATPase. Moreover, no linkage between these gene markers and RMR were found with the sib-pair analysis procedure. There are at least two reasons to justify the hypothesis that genes of the $\mathrm{Na}, \mathrm{K}-\mathrm{ATPase}$ were good candidates to account for some of the RMR variability. First, the $\mathrm{Na}, \mathrm{K}-\mathrm{ATPase}$ activity seems to be partly heritable. Differences in erythrocyte $\mathrm{Na}, \mathrm{K}$-ATPase activities have been found between ethnic groups $(24,25)$ but family members have generally similar erythrocytes enzyme activities (24). Second, the activity of this enzyme seems to be related to metabolic rate. For instance, an animal study found a strong correlation ( $r$ $=0.63$ ) between in vivo whole-body oxygen consumption and $\mathrm{Na}, \mathrm{K}-\mathrm{ATPase}$ activity in isolated soleus muscle (26). However, the latter finding perhaps overestimates the importance of $\mathrm{Na}, \mathrm{K}-\mathrm{ATPase}$ in metabolic rate. Other results suggest that only about 4-10\% of skeletal muscle total energy expenditure may be accounted for by the $\mathrm{Na}, \mathrm{K}-\mathrm{ATPase}(6)$. At rest, skeletal muscle metabolism represents about $28 \%$ of RMR (27). Thus, the energy expenditure accounted for by the $\mathrm{Na}, \mathrm{K}$-ATPase in the skeletal muscle ( mostly constituted by the $\alpha 2$ subunit) may represent only about $1-3 \%$ of the RMR. However, the expression of the $\alpha 2$ subunit occurs not exclusively in skeletal muscle but also in other tissues (i.e., neural tissue) and, therefore, the above estimates may not truly represent the putative effect of the $\alpha 2$ isoform on RMR.

Several reasons could explain the absence of association and linkage between the genes encoding the $\mathrm{Na}, \mathrm{K}-\mathrm{ATPase}$ and RMR. Based on the present results and the literature, the association is likely to be moderate at best and the number of subjects in the present study was perhaps not sufficient to detect it. Moreover, a locus that influences RMR in one direction may be compensated by another locus acting in the opposite direction. Thus, when variation at both loci are present, no differences in RMR are observable.

It is well known that the activity and/or the number of renal or muscular Na,K-ATPase are regulated by several factors such as catecholamines, insulin, thyroid hormones and may be potassium intake $(6,28,29)$. It can be hypothesized that the sensitivity of the Na,K-ATPase activity to these stimuli may be genetically determined. For instance, individuals with similar RMR may have different $\mathrm{Na}, \mathrm{K}-\mathrm{ATPase}$ activity responses to the insulin stimulus. In this case, RMR in healthy subjects is probably not the appropriate phenotype to investigate for association and linkage studies. Moreover, other factors than gene variability may be responsible for the

Table VI. ANOVA for Differences in RMR, Percent Fat, and RQ for the $\alpha 8.0-k b / 4.3-k b$ Haplotype*

\begin{tabular}{|c|c|c|c|c|c|}
\hline \multirow[b]{2}{*}{ Phenotype } & \multicolumn{3}{|c|}{$\alpha 2$ 8.0-kb/4.3-kb haplotypes } & \multirow[b]{2}{*}{$F$ ratio } & \multirow[b]{2}{*}{$P$} \\
\hline & 0 haplotype & 1 haplotype & 2 haplotypes & & \\
\hline RMR & $4.19 \pm 0.14(6)$ & $4.15 \pm 0.04(50)$ & $4.21 \pm 0.05(45)$ & 0.41 & 0.66 \\
\hline RQ & $0.788 \pm 0.019(6)$ & $0.830 \pm 0.006(50)$ & $0.814 \pm 0.006(45)$ & 3.25 & 0.04 \\
\hline \multicolumn{6}{|l|}{ Percent fat } \\
\hline $\mathbf{M}$ & $26.7 \pm 4.7(2)$ & $25.1 \pm 1.3(27)$ & $26.8 \pm 1.4(21)$ & 0.37 & 0.69 \\
\hline $\mathbf{F}$ & $29.8 \pm 3.2(4)$ & $35.3 \pm 1.3(23)$ & $38.3 \pm 1.3(24)$ & 3.57 & 0.04 \\
\hline
\end{tabular}

Mean \pm SE. Abbreviations: M, males; F, females. Groups with individuals sharing zero, one, and two $\alpha 2$ 8.0-kb/4.3-kb haplotypes are compared. * From the unrelated adults only. RMR and RQ are adjusted for FFM, FM, and age. Percent fat is adjusted for age. Number of subjects in parentheses. 
Table VII. P Values of the ANOVAs for Differences between Genotypes and Haplotypes in RMR, RQ, and \%FAT*

\begin{tabular}{llllll}
\hline & & & \multicolumn{2}{c}{ \%FAT } \\
\cline { 5 - 6 } \multicolumn{1}{c}{ Locus } & RMR & RQ & M & F \\
\hline Biallelic markers & & & & \\
$\quad \alpha 1$ & 0.85 & 0.44 & 0.47 & 0.55 \\
$\alpha 2$ exon 1 & 0.70 & 0.02 & 0.46 & 0.89 \\
$\alpha 2$ exon 21-22 & 0.53 & 0.60 & 0.06 & 0.05 \\
$\beta$ (MspI) & 0.98 & 0.15 & 0.53 & 0.95 \\
$\beta$ (PvuII) & 0.38 & 0.78 & 0.56 & 0.45 \\
Haplotypes & & & & \\
$\alpha 28.0 \mathrm{~kb} / 4.3 \mathrm{~kb}$ & 0.66 & 0.04 & 0.69 & 0.04 \\
$\beta 5.3 \mathrm{~kb} / 5.1 \mathrm{~kb}$ & 0.85 & 0.18 & 0.46 & 0.06 \\
& & & & \\
\hline
\end{tabular}

* From the unrelated adults only. RMR and RQ are adjusted for FFM, FM, and age. \%FAT is adjusted for age. For \%FAT, analyses were performed separately in males and females. Abbreviations: $\mathbf{M}$, males; F, females. Groups with individuals sharing zero, one, and two haplotypes are compared.

$\mathrm{Na}, \mathrm{K}-\mathrm{ATPase}$ response to insulin stimulus. For instance, insulin induces a translocation of the $\alpha 1$ and the $\beta 1$ subunits from the intracellular compartments to the plasma membrane in the mammalian skeletal muscle (30). It is not impossible that the variability of an unknown gene may regulate this $\mathrm{Na}, \mathrm{K}-\mathrm{ATPase}$ translocation.

Some studies have reported that ouabain binding by erythrocytes is lower in obese individuals than in normal individuals (31-33). However, other investigators have found no differences $(24,25,34-37)$. Interestingly, the $\mathrm{Na}, \mathrm{K}-\mathrm{ATPase}$ activity of obese human subjects has been found to be elevated in tissues or organs that consume much energy such as liver (38) and skeletal muscle (39). In the present study, there was a consistent trend for a difference in percent body fat between the genotypes at $\alpha 2$ exon $21-22$ locus in men $(P=0.06)$ and in women $(P=0.05)$. The variance in age-adjusted \%FAT explained by this gene variability amounted to $7 \%$ and $9 \%$ in men and women, respectively. The 4.3-kb allele was associated with a higher percentage of body fat and this trend was found in both genders (Table V).

Significant associations were observed between resting RQ and $\alpha 2$ exon 1 locus variants $(P=0.02)$ and $\alpha 28.0-\mathrm{kb} / 4.3-\mathrm{kb}$ haplotype $(P=0.04)$. The variance in adjusted RQ explained by DNA variation at this locus amounted to $5 \%$ and $6 \%$ for the $\alpha 2$ exon 1 locus and the $\alpha 28.0-\mathrm{kb} / 4.3-\mathrm{kb}$ haplotype, respectively. Interestingly, the same haplotype was also associated with a higher percentage of body fat in women $(P=0.04)$. The individuals who do not carry the $\alpha 28.0-\mathrm{kb} / 4.3-\mathrm{kb}$ haplotype show not only a lower RQ but also a lower body fat (Table VI). This is in accordance with the observation that individuals with low RQ are less at risk to gain weight (40). In addition, the RQ phenotype was linked with the $\beta$ gene $\mathrm{MspI}(P=0.04)$ and with the $\beta$ 5.3-kb/5.1-kb haplotype $(P=0.008)$. The sib-pair linkage program allowed to perform multiple linear regression with the proportion of genes identical by descent estimated from $\alpha 28.0-\mathrm{kb} / 4.3-\mathrm{kb}$ haplotype and $\beta$ 5.3-kb/5.1-kb haplotype as independent variables and the squared difference in RQ between sibs as the dependent variable. In this case, the $\beta$ 5.3$\mathrm{kb} / 5.1-\mathrm{kb}$ haplotype was more clearly linked with the squared RQ differences $(P=0.005)$. It appears, from the latter results, that the RQ is associated with the $\alpha 2$ subunit and linked with the $\beta$ subunit. Based on previous reports $(7,8)$, one could suggest that these results of associations and linkages between the $\alpha 2$ and $\beta$ gene with RQ are compatible with an action of the $\mathrm{Na}, \mathrm{K}-\mathrm{ATPase}$ on cellular FFA uptake. The $\alpha 2$ and $\beta$ genes are both located in the long arm of chromosome 1 , the estimated map location being 1 cen-q32 and $1 \mathrm{q}$ for the $\alpha 2$ and $\beta$ genes, respectively. Both genes may also be linked to some others that may have some influence on the RQ. For instance, muscle phosphofructokinase (map location: 1cen-q32) and liver pyruvate kinase (map location 1q21) enzymes genes are also located on the long arm of chromosome 1 and they may be reasonable candidate genes for variation in $R Q$.

In summary, the associations or linkages between the genes encoding the $\mathrm{Na}, \mathrm{K}$-ATPase peptides and RMR may be absent or weak. However, in both genders, percent body fat tends to be associated with $\alpha 2$ gene variability; the DNA markers percent body fat tends to be associated with $\alpha 2$ gene variability; the DNA markers accounting for at least $7 \%$ of the age-adjusted phenotype. Moreover, it appears that the $R Q$ is also associated with the $\alpha 2$ gene and linked with the $\beta$ gene of the $\mathrm{Na}, \mathrm{K}-\mathrm{ATPase}$. This strongly suggests that the $\mathrm{Na}, \mathrm{K}-\mathrm{ATPase}$ $\alpha 2$ and $\beta$ genes, or a neighboring gene, may be important in relative nutrient oxidation rates. Considering the potential importance of these findings, we would like to suggest that the present study needs to be replicated preferably on a large sample size.

Table VIII. Sib-Pair Linkage Analysis Results for RMR, \%FAT and RQ

\begin{tabular}{|c|c|c|c|c|c|c|c|}
\hline \multirow[b]{2}{*}{ Locus } & \multirow[b]{2}{*}{$N$} & \multicolumn{2}{|c|}{ RMR } & \multicolumn{2}{|c|}{ RQ } & \multicolumn{2}{|c|}{ \%FAT } \\
\hline & & $t$-ratio & $P$ & $t$-ratio & $P$ & $t$-ratio & $P$ \\
\hline \multicolumn{8}{|l|}{ Biallelic markers } \\
\hline$\alpha 2$ exon 1 & 103 & 0.59 & 0.72 & 0.00 & 0.50 & -0.68 & 0.25 \\
\hline$\alpha 2$ exon $21-22$ & 105 & 0.79 & 0.78 & -0.24 & 0.41 & -0.32 & 0.38 \\
\hline$\beta$ (MspI) & 94 & -0.07 & 0.47 & -1.78 & 0.04 & -0.04 & 0.49 \\
\hline$\beta$ (PvuII) & 90 & 0.16 & 0.56 & -0.02 & 0.49 & -0.78 & 0.22 \\
\hline \multicolumn{8}{|l|}{ Haplotypes } \\
\hline$\alpha 28.0 \mathrm{~kb} / 4.3 \mathrm{~kb}$ & 101 & -0.13 & 0.45 & -0.23 & 0.41 & 0.05 & 0.52 \\
\hline$\beta 5.3 \mathrm{~kb} / 5.1 \mathrm{~kb}$ & 77 & 0.11 & 0.54 & -2.47 & 0.008 & -0.12 & 0.45 \\
\hline
\end{tabular}

$N$, number of sib-pairs. 


\section{Acknowledgments}

We thank Dr. J. B. Lingrel for providing all the Na,K-ATPase probes, Dr. J. F. Moreel for his assistance in the haplotype analysis, Dr. J. A. Simoneau for his useful comments, and Ms. M. Chagnon for her expert technical help in the laboratory.

Olivier Dériaz is a fellow from the Medical Research Council of Canada. Louis Pérusse is a Research Scholar from the Québec Health Research Fund. This research was supported by grants from the Medical Research Council of Canada (MA 10499, PG 11811).

\section{References}

1. Ravussin, E., S. Lillioja, W. C. Knowler, L. Christin, D. Freymond, W. G. H. Abbott, V. Boyce, B. W. Howard, and C. Bogardus. 1988. Reduced rate of energy expenditure as a risk factor of body weight gain. N. Engl. J. Med. 318:467-472.

2. Bogardus, C., S. Lillioja, E. Ravussin, W. Abbott, J. K. Zawadzki, A Young, W. C. Knowler, R. Jacobowitz, and P. P. Moll. 1986. Familial dependence of resting metabolic rate. N. Engl. J. Med. 315:96-100.

3. Bouchard, C., A. Tremblay, A. Nadeau, J. P. Després, G. Thériault, M. R. Boulay, G. Lortie, C. Leblanc, and G. Fournier. 1989. Genetic effect in resting and exercise metabolic rate. Metab. Clin. Exp. 38:364-370.

4. Fontaine, E., R. Savard, A. Tremblay, J. P. Després, E. Poehlman, and C. Bouchard. 1985. Resting metabolic rate in monozygotic and dizygotic twins. Acta Genet. Med. Gemellol. 34:41-47.

5. Kelly, J. M., and B. W. McBride. 1990. The sodium pump and other mechanisms of thermogenesis in selected tissues. Proc. Nutr. Soc. 49:185-202.

6. Clausen, T., C. V. Van Hardeveld, and M. E. Everts. 1991. Significance of cation transport in control of energy metabolism and thermogenesis. Physiol. Rev. 71:733-773.

7. Weisiger, R. A., J. G. Fitz, and B. F. Scharschmidt. 1989. Hepatic oleate uptake. Electrochemical driving forces in intact rat liver. J. Clin. Invest. 83:411420.

8. Stremmel, W. 1988. Fatty acid uptake by isolated rat heart myocytes represents a carrier-mediated transport process. J. Clin. Invest. 81:844-852.

9. Randle, P. J., P. B. Garland, C. N. Hales, and E. A. Newsholme. 1963. The glucose fatty-acid cycle its role in insulin sensitivity and the metabolic disturbance of diabetes mellitus. Lancet. 1:785-789.

10. Lingrel, J. B., R. Young, and M. M. Schull. 1988. Multiple forms of the Na,K-ATPase: Their genes and tissue specific expression. Prog. Clin. Biol. Res. 268B: $105-112$

11. Schull, M. M., D. G. Pugh, and J. B. Lingrel. 1989. Characterization of the human Na,K-ATPase $\alpha 2$ gene and identification of intragenic restriction fragment length polymorphisms. J. Biol. Chem. 29:17532-17543.

12. Schull, M. M., D. G. Pugh, and J. B. Lingrel. 1990. The human $\mathrm{Na}, \mathrm{K}-\mathrm{ATPase} \alpha \mathrm{l}$ gene: characterization of the 5'-flanking region and identification of a restriction fragment length polymorphism. Genomics. 6:451-460.

13. Schull, M. M., D. G. Pugh, L. K. Lane, and J. B. Lingrel. 1990. Mspl and Pvull polymorphisms in the $\mathrm{Na}, \mathrm{K}$ ATPase $\beta$ subunit gene ATPIB1. Nucleic Acids Res. 18:1087.

14. Jéquier, E., K. Acheson, and Y. Schutz. 1987. Assessment of energy expenditure and fuel utilisation in man. Annu. Rev. Nutr. 7:187-208.

15. Meneely, G. R., and N. L. Kaltreider. 1949. Volume of the lung determined by helium dilution. J. Clin. Invest. 28:129-139.

16. Siri, W. E. 1956. The gross composition of the body. Adv. Biol. Med. Phys. 4:239-280.

17. Bouchard, C. 1985 . Reproducibility of body composition and adipose tissue measurements in humans. In Body Composition Assessment in Youth and Adults. Report of the Sixth Ross Conference on Medical Research. A. F. Roche, editor. Ross Laboratories, Columbus, OH. 9-13.
18. Southern, E. M. 1975. Detection of specific sequences among DNA fragments separated by gel electrophoresis. J. Mol. Biol. 98:503-517.

19. Feinberg, A. P., and B. Vogelstein. 1983. A technique for radiolabeling DNA restriction endonuclease fragments to high specific activity. Anal. Biochem. 132:6.

20. Thompson, E. A., S. Deeb, D. Walker, and A. G. Motulsky. 1988. The detection of linkage disequilibrium between closely linked markers: RFLPs at the AI-CII apolipoprotein genes. Am. J. Hum. Genet. 42:113-124.

21. Haseman, J. K., and R. C. Elston. 1972. The investigation of linkage between a quantitative trait and a marker locus. Behav. Genet. 2:3-19.

22. SAGE. 1992. Statistical Analysis for Genetic Epidemiology, release 2.1 Computer program package available from the Department of Biometry and Genetics, LSU Medical Center, New Orleans.

23. Rothman, K. J. 1990. No Adjustments are needed for multiple comparisons. Epidemiology. 1:43-46.

24. Mazelis, A. G., S. Larson, and F. Ginsberg-Fellner. 1987. Erythrocyte $\mathrm{Na}^{+}, \mathrm{K}^{+}$ATPase activity in childhood: regulation by genetic factors independent of body weight. Int. J. Obes. 11:561-570.

25. Beutler, E., W. Kuhl, and P. Sacks. 1983. Sodium-potassium-ATPase activity is influenced by ethnic origin and not by obesity. N. Engl. J. Med. 309:756-760.

26. Saddlier, S., and M. De Louise. 1986. Mouse soleus muscle $\mathrm{Na}, \mathrm{K}$ pump activity: direct correlation with in vitro and in vivo oxygen consumption. Horm. Metab. Res. 18:757-760.

27. Holliday, M. A. 1978. Body composition and energy needs during growth. In Human Growth. Volume 2. Postnatal Growth. F. Falkner and J. M. Tanner, editors. Plenum Press, New York. 117-139.

28. Clausen, T., and M. E. Everts. 1989. Regulation of the Na,K-pump in skeletal muscle. Kidney Int. 35:1-13.

29. Doucet, A. 1988. Function and control of $\mathrm{Na}, \mathrm{K}-\mathrm{ATP}$ ase in single nephron segments of mammalian kidney. Kidney Int. 34:749-760.

30. Hundal, H. S., A. Marette, Y. Mitsumoto, T. Ramlal, R. Blostein, and A. Klip. 1992. Insulin induces translocation of the $\alpha 1$ and $\beta 1$ subunits of the $\mathrm{Na}, \mathrm{K}-\mathrm{ATPase}$ from intracellular compartments to plasma membrane in mammalian skeletal muscle. J. Biol. Chem. 267:5040-5043.

31. DeLuise, M., E. Rappaport, and J. S. Flier. 1982. Reduced activity of red-cell sodium potassium pump in human obesity. N. Engl. J. Med. 303:10171022.

32. DeLuise, M., E. Rappaport, and J. S. Flier. 1982. Altered erythrocyte Na,K-pump in adolescent obesity. Metab. Clin. Exp. 31:1153-1158.

33. Klimes, I., M. Nagulesparan, R. H. Unger, S. L. Aronoff, and D. M. Mott. 1982. Reduced $\mathrm{Na}, \mathrm{K}-\mathrm{ATPase}$ activity in intact red cells and isolated membranes from obese man. J. Clin. Endocrinol. Med. 54:721-724.

34. Simat, B. M., R. R. Mayrand, A. H. L. From, J. E. Moreley, C. Billington, D. S. Fullerton, and A. Khalil. 1983. Is the erythrocyte sodium pump altered in human obesity? J. Clin. Endocrinol. Metab. 56:925-929.

35. Martin, L. F., W. L. Dean, L. M. Flint, C. P. Suarez, D. J. Ratcliffe, and D. E. Fry. 1983. Erythrocyte sodium-potassium stimulated adenosine triphosphatase activity is not related to obesity. J. Surg. Res. 34:473-478.

36. Monti, M., and J. Ikomi-Kumm. 1985. Erythrocyte heat production in human obesity. Microcalorimetric investigation of sodium-potassium pump and cell metabolism. Metab. Clin. Exp. 34:183-187.

37. Pasquali, R., E. Strocchi, P. Malini, F. Casimirri, N. Melchionda, E. Ambrosioni, and G. Labo. 1985. Heterogeneity of the erythrocyte $\mathrm{Na}, \mathrm{K}$ pump status in human obesity. Metab. Clin. Exp. 34:802-807.

38. Bray, G. A., J. G. Kral, and P. Björntorp. 1981. Hepatic sodium-potassium-dependent ATPase in obesity. N. Engl. J. Med. 304:1580-1582.

39. Charalambous, B. M., D. J. T. Webster, and M. A. Mir. 1984. Elevated skeletal muscle sodium-potassium-ATPase in human obesity. Clin. Chim. Acta. 141:189-195.

40. Zurlo, F, S. Lillioja, A. Esposito-del Puente, B. L. Nyomba, I. Raz, M. F. Saad, B. A. Swinburn, W. C. Knowler, C. Bogardus, and E. Ravussin. 1990. Low ratio of fat to carbohydrate oxidation as predictor of weight gain: study of 24-h RQ. Am. J. Physiol. 259:E650-E657. 